\title{
Oral health assessment protocol in primary care
}

\author{
Protocolo de Avaliação da Saúde Bucal na Atenção Básica
}

Suzely Adas Saliba MOIMAZ

Lúcia Maria Lima Lemos de MELO'

Cléa Adas Saliba GARBIN ${ }^{1}$

Artênio José Ísper GARBIN ${ }^{1}$

Nemre Adas SALIBA'

\section{ABSTRACT}

\section{Objective}

The aim of this study was to analyze the oral health service performance in a certain municipality and also to develop a diagnostic evaluation protocol of Oral Health in Primary Care.

\section{Methods}

This is a descriptive, quantitative and qualitative research. The research site chosen was in the city of Pereira Barreto, State of São Paulo Brazil, since it makes use of the Family Health Strategy as the structuring care model of the Health Care System in 100\% of the population as well as oral health teams implemented and oral health secondary care. Data were obtained through interviews with the manager, six dentists, six oral health assistants and six community health workers. Document analysis of the Municipal Health Plan was also conducted along with the Dental Health Agenda and on-site observation of the dental structure.

\section{Results}

The city Health Plan presents a detailed description of the municipality general situation, the oral health agenda recommends, in its implementation phase, the three main areas as a core in Family Health Strategy as follows: health unit, family and community. The survey found that the main form of access of the population to services was the spontaneous demand and there were only two Family Health teams without focus on oral health.

\section{Conclusion}

The analysis of the service performed; made possible to develop a protocol with specific Oral Health dimensions to support the manager in defining intervention strategies

Indexing terms: Health evaluation. Health management. Oral health. Primary health care.

\section{RESUMO}

Objetivo

Analisar o funcionamento do serviço de Saúde Bucal em um município e desenvolver um protocolo de avaliação diagnóstica da Saúde Bucal na Atenção Básica.

\section{Métodos}

Trata-se de uma pesquisa quanti-qualitativa, descritiva. O local da pesquisa foi Pereira Barreto, São Paulo, por apresentar a Estratégia Saúde da Família como modelo assistencial estruturante do Sistema de Atenção à Saúde em 100\% da população; equipes de saúde bucal implantadas; atenção secundária em saúde bucal. Os dados foram obtidos por meio de entrevistas com o gestor, 6 cirurgiões-dentistas, 6 auxiliares de saúde bucal e 6 agentes comunitários de saúde. Foram realizadas também análise documental do Plano Municipal de Saúde, Agenda de Saúde Bucal e observação in loco da estrutura odontológica.

\section{Resultados}

O município oferta serviços de saúde bucal com integração entre atenção básica e especializada, sendo a atenção básica ordenadora da rede. O Plano Municipal de Saúde apresenta descrição detalhada da situação geral do município; a agenda de saúde bucal preconizada em fase de implantação contempla os três eixos de atuação da Estratégia Saúde da Família: unidade de saúde família e comunidade. O inquérito identificou que a principal forma de acesso da população aos serviços era a demanda espontânea; havia duas equipes de Saúde da Família sem equipes de Saúde bucal.

\section{Conclusão}

A análise do funcionamento do serviço possibilitou desenvolver um protocolo com dimensões específicas de Saúde Bucal para subsidiar o gestor na definição de estratégias de intervenção.

Termos de indexação: Saúde bucal. Atenção primária à saúde. Avaliação em saúde. Gestão em saúde.

${ }^{1}$ Universidade Estadual Paulista Júlio de Mesquita Filho, Faculdade de Odontologia, Departamento de Odontologia Infantil e Social. Rua José Bonifácio, 1.193, Vila Mendonça, CEP 16015-050, Araçatuba, SP, Brasil. Correspondência para / Correspondence to: SAS MOIMAZ. E-mail: <sasaliba@foa. unesp.br>. 


\section{INTRODUCTION}

With the inclusion of oral health in the Family Health Strategy there has been a significant change in the dental model which was previously centered on pain relief and office assistance; now the orientation drives towards a health surveillance model that emphasizes health promotion and disease prevention'.

One of the managers biggest challenges concerning their commitment to develop health promotion, disease prevention, care and rehabilitation of individuals with the rational use of resources is to focus on people's health as well in their social and physical environment in which they live and work and not just thelr illnesses, themselves ${ }^{2}$.

This user-centered model highlights the incorporation of diagnostic practice as the various levels of care and it becomes an important health service tool for identifying problems and thus brings about successful actions.

The diagnosis prevents the manager to be "caught off guard" by a demand which was not planned ${ }^{3}$.

The actions and health services mirrored in the knowledge of the reality of each municipality is essential in order to effectively promote a practical and problemsolving.strategy Therefore, considering that health management is difficult due to issues as such: problem complexity to be solved, the nature of assistance provided ${ }^{4}$ together with the too few studies provided to guide the Oral Health Manager in defining the proper intervention strategies and also added to the fact that many managers take the service without adequate training to carry out their function, this study proposes an oral health diagnostic evaluation protocol in primary care to guide the definition of intervention strategies.

\section{METHODS}

It is a descriptive, quantitative and qualitative, research conducted in the city of Pereira Barreto, with 24,962 inhabitants 5 , a tourist resort based in the northwest of São Paulo State and its Regional Health Department belongs to the city of Araçatuba, State of São Paulo, Brazil. The Municipal Health Plan, during 2014-20176, reports that the population is predominantly urban and with $7 \%$ in the countryside; this percentage varies during the year due to the landless people camps. The economic activity of the municipality is based on agriculture and sugarcane.
The criteria for choosing the study site were: adoption by the council of the Family Health Strategy (FHS) as a structural assistance model of the Health Care System, assisting $100 \%$ of the urban population, the existence of Oral Health Teams deployed in six health teams, a Dental Specialty Center implemented in the city, a family health Support Unit (NASF) as well as easy information approaches.

Data were collected through 19 professionals interviews: Oral Health Municipal Coordinator, 6 Dentists (DDS) 6 Oral Health assistants (ORA), 6 Community Health Agents (CHA) being one of each Oral Health. The questionnaires were pre-tested in another municipality to check necessary changes and the data were processed through Microsoft Excel 2008 program.

Content analysis methodology was used for the open questions and the outcome of the investigation described as follows: dental infrastructure, work access regulation, organization and assessment strategies. They were also conducted document analysis of the Municipal Plan of Health and Oral Health Agenda and the on-site observation of the dental structure. The Municipal Health Plan (SMP) of Pereira Barreto presented the following variables according to Ordinance number 2.1357: a) situational analysis - of the health system structure, health care networks, hygiene conditions, access flows, financial resources, work management and health education; b) science, technology, production and innovation in health and management; c) guidelines, objectives, targets definitions and indicators; d) monitoring and assessment process.

The Oral Health Agenda showed focus on the three main areas of activity of the Family Health Team: health unit, family and community.

As for on-site observation the conservation status of the equipment was assessed, as well as the consumption material available and oral health teams work procedures disposed in the Family Health.

Teams After collecting the data, work towards situational diagnosis began; based on theoretical and practical finding. The results were problematized in a workshop held in the city with the teams involved, based on the National Oral Health Policy Guidelines and Continuing Education.

The study was approved by the Ethics Committee for Research with Human Beings of the Dental School of the city of Araçatuba- State of São Paulo (FOA / UNESP), under the number 32482613.3.0000.5420, in 2014. The 
professionals were informed about the purpose of the study and signed a free consent form.

\section{RESULTS}

In order to carry out the situational diagnosis, the analysis of the Municipal Health Plan and the oral health agenda besides on-site observation and surveys with health teams, were performed.

\section{Municipal Oral Health document analysis}

Several documents can be a source of information about municipal oral health. In the city of Pereira Barreto the Municipal Health Plan (SMP) was analyzed and it was observed that it is well- structured, presenting clearly defined goals and objectives, detailed description of the general situation of the municipality, critical analysis of epidemiological data and intervention proposals on the problems identified. The plan highlights strategic intervention to solve problems such as the expansion and improvement of infrastructure, need to hire personnel and financial resource improvement. It has been reported that the dental care demand for adult population had been deprived while risk groups are prioritized for treatment, in the agenda.

It was observed that in the Municipal "Health Structure" Plan the item referring to the Regional Laboratory of Dental Prosthesis (RLDP) was not mentioned and it is also worth noting the lack of inclusion of oral health actions in primary care networks and external control of fluoride in drinking water conducted by the Center for Research in Public Health in the Graduate Program in Preventive and Social Dentistry (NEPESCO) of the Faculty Araçatuba of Dental FOA / UNESP, plus the inclusion in the Municipal Health Structure plan, the essential oral health integration with Education through the School Health Program (SHP), a fact which was verified by on-site observation.

\section{Interviews}

\section{Infrastructure characterization}

It was found that the care model adopted by the city of Pereira Barreto is $100 \%$ family health oriented, presenting six oral health teams, highlighting the Primary care Health Unit as the main gateway to the system, focusing on family and not restricted to specific age groups.
Respondents have reported that the consumption of material used is enough and of excellent quality for the assistance achievement. On-site observation showed that the dental equipment were in good condition.

A Center for Dental Specialties (CDS) and a Regional Laboratory of Dental Prosthesis (RLDP) has been implemented. The CDS began its activities in 2013 as type I CDS, with three dental chairs endodontics procedures, minor oral surgery, periodontics, disable people assistance as well as oral cancer detection and diagnosis. Total and removable dentures are performed by the RLDP.

Human resources are not enough to perform the dental procedures. Six oral health teams $(\mathrm{OHT})$ for eight Family Health Teams (FHT) are deployed.

The Municipal Health Council has its own headquarters and Local Health Councils are deployed in Primary Care Health Units and in the Dental Center.

The Information System for Health operates using e-sus Primary Care for users' registration.

\section{Treatment approach and regulation}

Respondents mentioned the following ways of patient admittance to dental treatment: spontaneous demand, referral by community health workers (CHW), programmatic groups (diabetics, hypertension, obesity, disabled people) and risk criteria.

The risk screenings are performed by all ESB in school and in some health facilities. The reference guide and counter is the document adopted for referring patients to specialty service.

\section{Work organization procedures}

The municipal planning process is performed by oral health teams along with other professionals of the Primary Care Health Unit. The integration mostly corresponded to the actions carried out towards children, pregnant women, hypertension groups, diabetic patients and lower participation in the adolescent groups.

As an intersectional action, community health agents perform supervised tooth brushing through the Health Program in Schools (HPS).

It was reported, in interviews, that the following Health Care Networks are functioning: Stork Networka special programmer instituted on June $24^{\text {th }}, 2011$, (ordinance numbered 1459), which is oriented to pregnant women, reproduction planning, childbirth and postpartum. It is also reported the presence of other networks as 
follows: Psychosocial Care (PCN), Emergency and Urgent needs, Health Network for Chronic Disease and disabled people. The oral health actions are inserted in the stork networks in order to monitor pregnant women and babies and in the Chronic Disease networks such as Diabetes, Hypertension and Obesity.

The health primary care team's employees who obtained excellent and good certification receive financial incentive from the Access Improvement and Primary Care Quality Programme (AIPCQP).

Most of the dentists interviewed reported difficulty to prioritize risk groups and fulfill the existing schedule in the city:" We are not able to follow the schedule since the demand is too great."

On the Municipal Health Plan (dated 2014-2017) ${ }^{6}$, the manager says there is impairment on the adult dental care demand and during the implementation of the survey, the dentist's speech demonstrated the difficulty in dealing with spontaneous demand: "Patients arrive at any time and already want to be assisted, they have no idea of schedule and demand."

In this context, the effective implementation of a planned schedule as well as risk rating assistance was recognized by respondents as tools for the organization of municipal demand.

\section{Assessment strategies}

When asked if the Oral Health Team (OHT) uses results of epidemiological Oral Health indices for planning and evaluation of actions in their area, 100\% of respondents answered negatively. They reported that epidemiological survey was conducted in the municipality as a whole. In the areas of coverage of the teams risk criteria are performed in school for the action planning, in order to guide the Oral Health Team (OHT). Concerning the productivity, parameters are used in all teams.

The assessments and monitoring of the results achieved are monthly held for all teams through production data and discussed at the meetings. Every day, dentists computerize Basic Health Units (BHU) production data. It was reported by a $100 \%$ of the dentists that a standardized form is applied in order to hear the public about Dentistry action fulfillment.

Tables 1 and 2 present evaluation proposals for oral health actions in primary care, with the collected source and theoretical reference used for analysis of Municipal Health Plan (MHP) data, the applied questionnaire and oral health agenda, important to support the manager in decision-making. These proposals are the result of a development based on the study of the city of Pereira Barreto, the National Oral Health Policy and in the literature.

Table 1. Evaluation proposal for the oral health organization actions of primary care in the Municipal Health Plan (MHP), Araçatuba, 2014.

\begin{tabular}{|c|c|c|c|c|}
\hline Amplitude & \multicolumn{2}{|c|}{$\begin{array}{l}\text { Municipal Health Plan (MHP) items to be } \\
\text { analyzed }\end{array}$} & Suggestions for oral health area assessment & Referencies \\
\hline & $\begin{array}{l}\text { Health System } \\
\text { Structure }\end{array}$ & $\begin{array}{l}\text { Health surveillance, } \\
\text { Primary Care, Specialized } \\
\text { Outpatient Care, Hospital } \\
\text { Care, Emergency Assistance } \\
\text { and Urgent needs, } \\
\text { Pharmaceutical Services, } \\
\text { Municipal Health Secretariat }\end{array}$ & $\begin{array}{l}\text { Fluoridation of public water supplies; } \\
\text { Fluorine external control; } \\
\text { Strategy adopted in primary care: } \\
\text {-Health Family: Implementation of the Oral } \\
\text { Health Teams } \\
\text { Family Health, Oral Health actions in CSFH } \\
\text { (Centers of Support for Family Health); } \\
\text {-Traditional-model: Identification of the } \\
\text { establishment which develop oral health } \\
\text { actions: Basic health Units, isolated offices, } \\
\text { dental centers, mobile units; } \\
\text { Oral health actions developed in the Health } \\
\text { School Programme (HSP) } \\
\text { OEC; RLDP; Dentistry in the hospital service; } \\
\text { hire an oral health coordinator }\end{array}$ & $\begin{array}{l}\text { Ordinance } \mathrm{n}^{0} 2.135, \\
\text { Pact system: SISPACTO } \\
\text { Policy Guideline for } \\
\text { National Oral Health, } \\
\text { DEC 6.286/2007: health } \\
\text { program at school } \\
\text { Technical invoice No } \\
01 / 2014 \mathrm{MS} \text {, } \\
\text { Decree } 124-\text { Federal } \\
\text { Council of Dentistry, } \\
\text { Ordinance 2488: AB } \\
\text { National Policy. }\end{array}$ \\
\hline \multirow[t]{4}{*}{$\begin{array}{l}\text { Situacional } \\
\text { analises }\end{array}$} & $\begin{array}{l}\text { Health care } \\
\text { networks }\end{array}$ & $\begin{array}{l}\text { Stork network, Psychosocial } \\
\text { Care Network (PSCN),Urgent } \\
\text { needs and Emergency } \\
\text { network, Care Network } \\
\text { for Chronic Diseases, Care } \\
\text { Network for People with } \\
\text { Disabilities }\end{array}$ & Oral Health Inclusion in networks. & $\begin{array}{l}\text { Ordinance } n^{\circ} 1459 \\
\text { Ordinance } n^{\circ} 3.088 \\
\text { Ordinance } n^{\circ} 1.600 \\
\text { Ordinance } n^{\circ} 483 \\
\text { Ordinance } 793\end{array}$ \\
\hline & $\begin{array}{l}\text { sociosanitary } \\
\text { status }\end{array}$ & $\begin{array}{l}\text { Socio-demographic and } \\
\text { Epidemiological Profile }\end{array}$ & $\begin{array}{l}\text { Oral health rates by age group or specific } \\
\text { group tooth decay: OEC, DMF } 12 \% \text { of } \\
\text { children aged } 5-5 \text { and others. }\end{array}$ & \multirow{2}{*}{$\begin{array}{l}\text { Guidelines for Primary } \\
\text { Care in Oral Health of } \\
\text { the Municipal Health } \\
\text { Department of São } \\
\text { Paulo-2009 }\end{array}$} \\
\hline & Access Flow & $\begin{array}{l}\text { Health Basic Unit, Hospital, } \\
\text { AME, Family Health support } \\
\text { Centre, OEC }\end{array}$ & $\begin{array}{l}\text { Risk screening flows screening (Example: } \\
\text { decay, oral lesions), and RLDP, Reference } \\
\text { Guide and counter references. }\end{array}$ & \\
\hline & Financial AIDS & $\begin{array}{l}\text { Federal, State and Municipal } \\
\text { financial resources }\end{array}$ & $\begin{array}{l}\text { Financial resource for oral health received } \\
\text { from three levels of government, including } \\
\text { special programs. }\end{array}$ & $\begin{array}{l}\text { OHT resource, OEC, RLDP, } \\
\text { São Paulo Smile } \\
\text { Programme }\end{array}$ \\
\hline
\end{tabular}




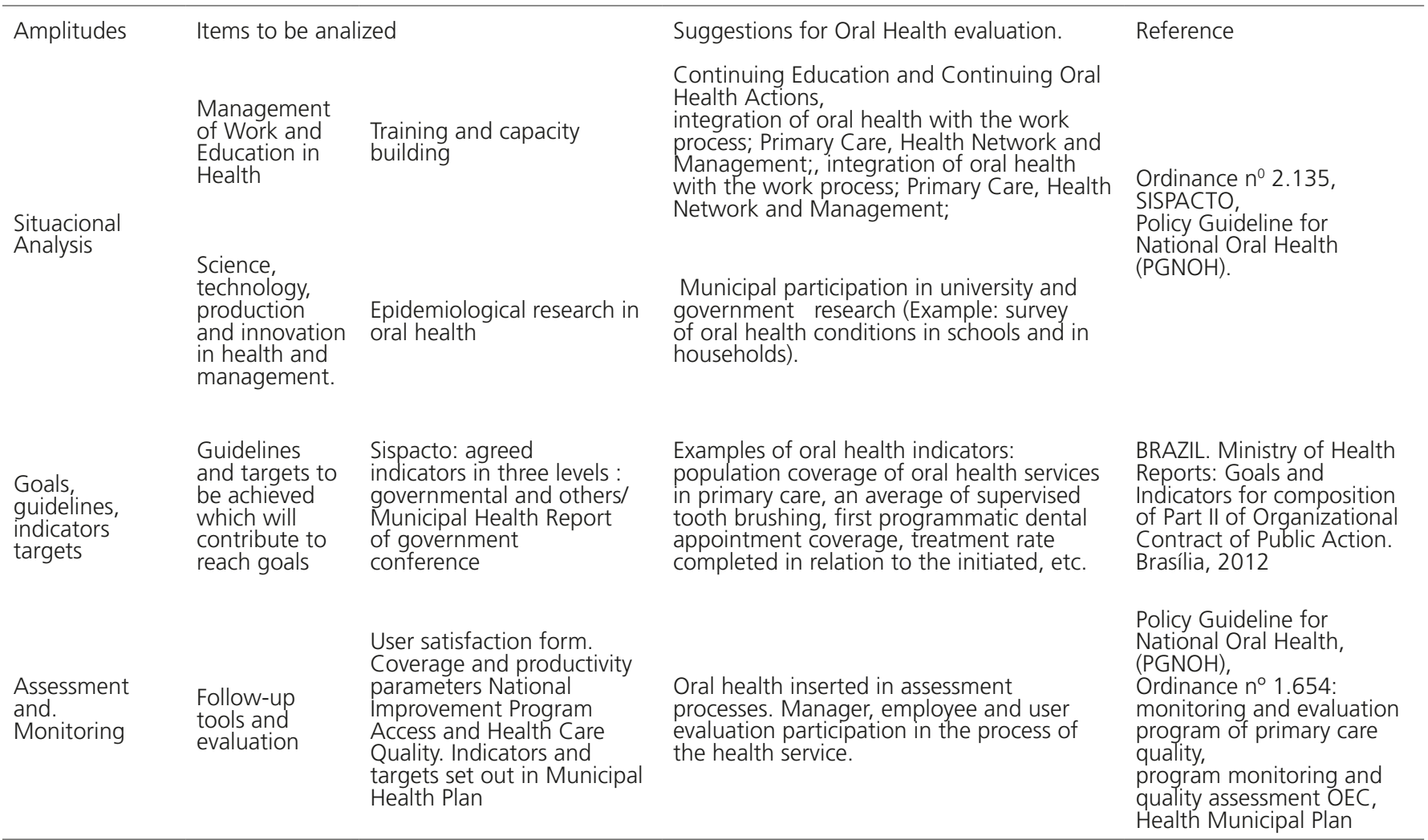

Table 2. Proposal evaluation of the organization of oral health actions of primary care in the questionnaire and oral health agenda, Araçatuba, 2014.

\begin{tabular}{|c|c|c|c|}
\hline Tool & Amplitude & $\begin{array}{l}\text { Analyzed items in the questionnaire and Oral health } \\
\text { Agenda }\end{array}$ & Reference \\
\hline \multirow{4}{*}{ Questionnaire } & Infrastructure & $\begin{array}{l}\text { Facility resources: number of units providing dental } \\
\text { service: BHU, OEC, RLPD, isolated offices, mobile units, } \\
\text { Dental Center } \\
\text { Human-resource dentists, (DDS), oral health assistants } \\
\text { (OHA), Health Community Assistants (OCA) }\end{array}$ & \multirow{3}{*}{$\begin{array}{l}\text { Ordinance } \mathrm{n}^{\circ} \text { 2.488: AB National } \\
\text { Policy, } \\
\text { Policy Guideline for } \\
\text { National Oral Health } \\
\text { (PGNOH), } \\
\text { Policy of Humanization and } \\
\text { Continuing Education. }\end{array}$} \\
\hline & Acess and regulation & $\begin{array}{l}\text { Spontaneous demand, priority groups, risk screening, } \\
\text { referral and counter-referral Guide }\end{array}$ & \\
\hline & $\begin{array}{l}\text { Work organization } \\
\text { procedures }\end{array}$ & $\begin{array}{l}\text { Care model adopted, Planning, Intersectoriality: Ex: Health } \\
\text { School Programme (HSP), Teamwork: multidisciplinary, } \\
\text { interdisciplinary, Care Networks in Health, Humanization } \\
\text { Technical Group, risk classification, welcoming }\end{array}$ & \\
\hline & Assessment strategies & $\begin{array}{l}\text { User satisfaction form, coverage parameters and } \\
\text { productivity, (PPC) }\end{array}$ & \multirow{7}{*}{$\begin{array}{l}\text { Report primary care information } \\
\text { system (PCIS) } \\
\text { Ordinance } n^{\circ} 2.488 \text { : AB National } \\
\text { Policy, } \\
\text { Policy Guideline for National Oral } \\
\text { Health, } \\
\text { Agenda recommended in the city. }\end{array}$} \\
\hline \multirow{6}{*}{$\begin{array}{l}\text { Oral health } \\
\text { agenda }\end{array}$} & Priority groups & $\begin{array}{l}\text { School children, pregnant women, patients with } \\
\text { hypertension, diabetic patients, the elderly, babies, } \\
\text { participants who receive governmental financial help, } \\
\text { others. }\end{array}$ & \\
\hline & $\begin{array}{l}\text { Urgent needs and free } \\
\text { demand }\end{array}$ & Daily periodicity & \\
\hline & Team meetings & $\begin{array}{l}\text { Frequency: Weekly or another, integration with the Family } \\
\text { Health Team }\end{array}$ & \\
\hline & Home visits & Scheduled according to the needs & \\
\hline & Administrative activities & Daily computorized fulfillment & \\
\hline & Risk Evaluation & $\begin{array}{l}\text { School, priority groups of Basic Health units and others, } \\
\text { campaigns }\end{array}$ & \\
\hline
\end{tabular}




\section{DISCUSSION}

The completion of the service situational diagnosis by analyzing the Municipal Plan of Health, Oral Health Agenda, the on-site observation and surveys with health teams provided a better understanding of the recommended oral health model in the municipality, with the primary care provided that the coordinator conducts care and network organization. Although the protocol has been built based on the model of Health of the family experience, it may be valid for other welfare arrangements, once they follow the principles of primary health care policy and oral health.

In the Municipal Health Plan analyzed, it was reported that it had been $w$ prepared in a participatory way with users' representatives, workers and managers; and approved by the Municipal Health Council. The MHP is a central planning tool for the implementation of all initiatives in the health of every sphere of management of the Unified Health System (SUS) for the period of four years, it states the government commitments to the health sector and reflects based on the situational analysis, the health needs of population?. The collective construction of a MHP promotes result co-responsibility.

Historically, the council used to hold an oral health care model oriented to school. There has been the expansion of the service with the implementation of oral health in the Family Health Strategy and then the municipal management ensures dental specialty services as a reference for primary care. The municipality was entitled to receive from the federal government a monthly financial resource for the making of dentures and procedures on specialty center (OEC) according to a range of production? . $^{2}$

Changing the care model with the Oral Health incorporated into the Family Health Strategy promotes increased coverage, effectiveness in meeting the demands of the population and / achieving measures of collective targets $^{9}$. It also provides greater scope of actions aimed at promotion and prevention, giving priority to collective activities and service to specific groups ${ }^{10}$.

The not $100 \%$ population coverage generates a large spontaneous demand in some areas. In addition to the deficit ( $n=2$ ) of oral health teams, the existence of a floating population, consisting of sugar cane workers, camps, settlements, changes the epidemiological, demographic and social profile, increasing demand for the service. For the reorganization of actions and services in oral health, it is recommended that the criterion of a
Health Family Strategy (HFS) for each oral health team to ensure basic services for oral health in all health facilities.

There is an impaired demand for endodontics, confirming that the expansion of the health care system in secondary and tertiary care has not kept pace in the dental sector, the growth in supply of primary care services".

The municipality is included in "Smile Program São Paulo" of the State Government. The "Smile Program São Paulo" was created in 2006 in order to contribute to the maintenance, expansion and modernization of services in oral health of the SUS at the level of primary care. The feature allows a dental management with the acquisition of better quality consumables for preventive and curative actions.

The Municipal Health Council and Local Health Councils deployed in Basic Health Units and Dental Centre have been monitoring the actions developed in the municipality and the district Health Unit, respectively ${ }^{6}$. Thus, popular participation ensures a management committed to the collective interest.

As the computerization of production, the municipality has started the e-sus deployment: software to operationalize the Information System for Health for Primary Care (SISAB), which happens to be the current information system for funding and adherence to programs and strategies of the National Primary Care Policy ${ }^{11}$. The e-sus enables an evaluation with more reliable results, since the indicators are closer to the reality of the teams.

One of the tools used to rationalize the flow is the screening risks. Screening tests can be performed in the following situations: in health facilities with established groups in the community, in households for planning, organizing and referral to treatment and tests for the diagnosis of oral cancer ${ }^{12}$. It is important that trials are conducted in the health units for the organization of the work due to the vulnerability of users, giving a responsible referral to demands ${ }^{13}$

The reference and counter ensure mutual referral of patients concerning levels of complexity ${ }^{14}$. The proper functioning of reference and counter system is essential for completion of the treatments and thus better service resolution.

A positive aspect is the planning procedures to be performed shared by the teams, which makes it possible to understand the main problems and needs of the population. It is important that planning is not carried out individually, intuitively and without the least systematic institutional socialization for the elaborated projects ${ }^{15}$. 
Among the educational activities performed in the community is the integration of oral health with Education through the School Health Program(SHP) The SHP is used strategically for the integration and ongoing coordination between policies and education and health activities with the participation of the school community; involving the Family Health Teams and basic education. Among the health actions planned under the SHP is the assessment of health and oral hygiene ${ }^{16}$. There had been on-site supervised tooth brushing, and educational activities realized by community health workers in the school environment.

There is no function overloading to the oral health coordinator between management and dental care activities. They are considered management activities once they track the performance of each team through monthly assessments of health indicators and produced reports, meetings in the Department of Health and visits to Health units $^{17}$. The availability of workload for the practice of management for the purpose of planning, monitoring and evaluation of actions is essential.

The transfer of the financial incentive in the Monitoring Program and Quality Assessment (MPQA) to the professionals mentioned by respondents is a valuable action to promote their work. The MPQA is a federal program that aims to induce increased access and improved primary care quality which guarantee a quality standard comparable to local, regional and national quality ${ }^{18}$.

The Oral health agenda, a tool which allows the equity reorientation of oral health practices during the work procedures. It was collectively built considering the National Oral Health Policy Guidelines which are as follows: individual, collective actions, promotion and prevention, carried out in three areas of team performance such as health unit, community and home. It also includes priority groups: pregnant women, diabetics' patients, hypertensives, bolsa-familia (a financial governmental help), school, urgent demand, staff meetings and administrative activities. It was developed concerning the diagnosis of the needs of defining the number of available spontaneous and scheduled appointments, the number of routine appointment returns, staff meetings, administrative and educational activities as well as risk assessment.

It is important that the dental schedule (oriented through SUS guidelines), built from the accomplished diagnosis, prioritizing needs identified at team meetings; as well as the analysis of the Primary Care Information System report (PCISR).
Through the Information System of Primary Care, is obtained on families' registrations, housing and sanitation conditions, health status, production and composition of health teams ${ }^{19}$. On the agenda, there could be different priority for micro areas depending on the situation of each one.

Welcoming the patients is the National Humanization Policy tool being implemented in the Units; the user is assisted according to the vulnerability assessment, severity and risk. Such a procedure was included in the SUS table through Ordinance n0 1442 of 17 December $2014^{20}$.

Respondents have recognized the importance of carrying out the epidemiological survey in the team's coverage area. Data from periodic epidemiological surveys, especially the team's coverage area, are essential to the needs assessment, planning, implementation and evaluation of oral health actions ${ }^{21}$. In order to guide the action planning a triage risk of caries, periodontal condition, need for prostheses and evaluation of soft tissue are performed.

In order to guide the Oral Health Team (OHT) concerning the productivity, parameters are used in all teams. Parameters represent ideal technical recommendations, constituting a reference to guide the SUS managers of the three levels of government in planning, scheduling and prioritization of health actions to be developed ${ }^{22}$. In order to highlight the expansion and qualification of care, it is recommended that $75 \%$ to $85 \%$ of the contracted hours are devoted to the care and 15\% to $25 \%$ to other activities such as planning, training and collective activities 9 . Besides the parameters, it is important that the teams' production, informed in the Outpatient Information System, can really subsidize the evaluation of oral health policies by providing, managers, with utmost relevant material for their decision-making ${ }^{23}$.

In relation to a tool for listening to the public's satisfaction concerning the fulfillment of actions in the field of dentistry, a specific form is used. The user's perception scales reflects the actions that have been developed in the healthcare industry and serves as targeting vector and work planning ${ }^{24}$.

\section{CONCLUSION}

The municipality offers dental services provided by basic and specialized care integration, and primary 
cares leads network attention, however, the spontaneous demand is still a challenge to be faced. Knowledge of oral health service provided the need for development of a diagnostic evaluation protocol of primary care in order to support the manager who guides the municipal oral health coordination as well in essential intervention strategy definitions, with activities based on the principles of universality, equity and comprehensive care.

\section{REFERENCES}

1. Pimentel FC, Albuquerque PC, Martelli PJL, Souza WVS Acioli RML. Caracterização do processo de trabalho das equipes de saúde bucal em municípios de Pernambuco, Brasil, segundo porte populacional: da articulação comunitária à organização do atendimento clínico. Cad Saúde Pública. 2012;28(Suppl):s146-s157. doi: http://dx.doi.org/10.1590/ S0102-311X2012001300015

2. Starfield B. Atenção primária: equilíbrio entre necessidades de saúde, serviços e tecnologias. Brasília (DF): Ministério da Saúde; 2002 [citado 2014 Ago 15]. Disponível em: <http://bvsms. saude.gov.br/bvs/publicacoes/atencao_primaria_p1.pdf>.

3. Brasil. Conselho Nacional de Secretários de Saúde. Atenção Primária e Promoção da Saúde. Brasília: CONASS; 2007 [citado 2014 Ago 15]. Disponível em: <http://bvsms.saude.gov.br/bvs/ publicacoes/colec_progestores_livro8.pdf $>$.

4. Dussault G. A gestão dos serviços públicos de saúde: características e exigências. Rev Adm Pública. 1992;26(2):8-19.

5. Instituto Brasileiro de Geografia e Estatística (IBGE). Cidades@. Pereira Barreto [citado 2014 Ago 15]. Disponível em: <http:// cidades.ibge.gov.br/xtras/perfil.php?lang=\&codmun=353740>.

6. Brasil. Ministério da Saúde. Plano Municipal de Saúde 20142017 [citado 2014 Ago 15]. Disponível em: <http://aplicacao. saude.gov.br/sargsus/login!carregarPagina.action>

7. Brasil. Portaria n. 2.135, de 25 de setembro de 2013. Estabelece diretrizes para o processo de planejamento no âmbito do Sistema Único de Saúde (SUS). [online] 2013. Diário Oficial da União 2013, set 26 [citado 2014 Ago 10]. Disponível em: <http://bvsms.saude.gov.br/bvs/saudelegis/gm/2013/ prt2135_25_09_2013.html>.

8. Brasil. Portaria n. 4.262, de 30 de dezembro de 2010. Estabelece recursos a serem incorporados ao Teto Financeiro de Média e Alta Complexidade dos Estados e Municípios. [online]. 2010. Diário Oficial da União 2010, dez 31. [citado 2014 Ago 10]. Disponível em: <http://189.28.128.100/dab/docs/legislacao/ portaria4262_30_12_10.pdf>.

9. Brasil. Ministério da Saúde (BR). Diretrizes da Política Nacional de Saúde Bucal. Brasília (DF): Ministério da Saúde; 2004 [citado 2014 Ago 10]. Disponível em: <http://conselho.saude.gov.br/ web_comissoes/cisb/doc/politica_nacional.pdf>

10. Farias MAV, Moura ERF. Saúde bucal no contexto do Programa Saúde da família do Município de Iracema, no Ceará. Rev Odontol UNESP. 2003;32(2):131-7.

\section{Collaborators}

SAS Moimaz and LMLL MELO participated in the conception, design, analysis and interpretation of data and writing of the article. CAS GARBIN, AJI GARBIN and NA SALIBA participated in the analysis and interpretation of data and writing of the article.

11. Brasil. Portaria n. 1.412, de 10 de julho de 2013. Institui o Sistema de Informação em Saúde para a Atenção Básica (SISAB). Diário Oficial da União. [online]. 2013, jul 11 [citado 2014 Ago 10]. Disponível em: <http://www.revodontolunesp.com.br/files/ v32n2/v32n2a09.pdf>

12. São Paulo (Estado). Secretaria da Saúde de São Paulo. Manual de orientações em saúde bucal para o SUS no âmbito do estado de São Paulo. São Paulo (SP): Secretaria de Estado da Saúde; 2010

13. Chagas HMA, Vasconcellos MPC. Quando a porta de entrada não resolve: análise das unidades de saúde da família no município de Rio Branco, Acre. Saúde Soc. 2013; 22(2): 377-88.

14. Serra CG, Rodrigues PHA. Avaliação da referência e contra referência no Programa Saúde da Família na Região Metropolitana do Rio de Janeiro (RJ, Brasil). Cinch Saudi Collative. 2010; 15(3):3579-3586. doe: http://dx.doi.org/10.1590/S141381232010000900033

15. Brasil. Ministério da Saúde. Saúde Bucal. Brasília (DF): Ministério da Saúde; 2008 [citado 2014 Ago. 10]. Disponível em: <http:// bvsms.saude.gov.br/bvs/publicacoes/saude_bucal.pdf $>$.

16. Brasil. Decreto n. 6.286, de cinco de dezembro de 2007. Institui o Programa Saúde na Escola - PSE, e dá outras providências. Diário Oficial da União. [online]. 2007, dez seis [citado 2014 Ago. 10]. Disponível em: <www.planalto.gov.br/ccivil_03/_ ato2007-2010/2007/decreto/d6286.htm>.

17. Coriolano MWL, Albuquerque GA, Araújo NS, Oliveira MA, Lima MM. Vivenciando o processo de municipalização do SUS no município de Juazeiro do Norte (CE). Ciênc. Saúde Coletiva. 2010; 15(5): 2447-2454. Dói: http://dx.doi.org/10. 1590/S141381232010000500019

18. Brasil. Portaria n. 1.654, de 19 de julho de 2011. Institui, no âmbito do Sistema Único de Saúde, o Programa Nacional de Melhoria do Acesso e da Qualidade da Atenção Básica (PMAQ$A B)$ e o Incentivo Financeiro do PMAQ-AB, denominado Componente de Qualidade do Piso de Atenção Básica Variável - PAB Variável. Diário Oficial da União. [online]. 2011, jul. 20. Disponível em: http://bvsms.saude.gov.br/bvs/saudelegis/ gm/2011/prt1654_19_07_2011.html

19. Brasil. Ministério da Saúde. SIAB: Sistema de Informação da Atenção Básica. Disponível em: http://www.2.datasus.gov.br/ $\mathrm{SIAB} /$ index. php?area $=01$

20. Brasil. Portaria no 1.442, de 17 dezembro de 2014. Inclui na Tabela de Procedimentos do SUS o procedimento Acolhimento com Classificação de Risco. Diário Oficial da União. [online]. 2014, dez 18 [citado 2014 Ago 10]. Disponível em: <http:// www.lex.com.br/legis_26308252_PORTARIA_N_1442_DE_17_ DE_DEZEMBRO_DE_2014.aspx> 
21. São Paulo (Estado). Secretaria de Estado da Saúde (SP). Conselho de Secretários Municipais de Saúde. SUS no Estado de São Paulo: atualizações para os gestores municipais. São Paulo: PoloBooks; 2013 [citado 2014 Ago 10]. Disponível em: <http:// www.cosemssp.org.br/downloads/livro-cosemssp-sessp.pdf>.

22. Brasil. Portaria n. 1.101, de 12 de junho de 2002. Estabelece que os parâmetros de cobertura assistencial sejam estabelecidos pela Direção Nacional do Sistema Único de Saúde-SUS aprovados pelo Conselho Nacional de Saúde. Diário Oficial da União. [online]. 2002, jun 12 [citado 2014 Ago 10]. Disponível em: <http://www1.saude.ba.gov.br/regulasaude/2009/PN\%20 PORTARIAS\%202009/nvos\%20pdfs\%202009/PT\%20GM\%20 1101\%2012.06.2002.pdf>
23. Linhares LL, Bordin R. Caracterização do modelo de atenção à saúde bucal de uma capital estadual brasileira, utilizando o sistema de informações ambulatoriais do Sistema Único de Saúde. RGO, Rev Gaúcha Odontol. 2012;60(1):41-7.

24. Moimaz SAS, Marques JAM, Saliba O, Garbin CAS, Zina LG, Saliba NA. Satisfação e percepção do usuário do SUS sobre o serviço público de saúde. Physis. 2010;20(4):1419-1440. doi: http://dx.doi.org/10.1590/S0103-73312010000400019

Received on: 12/2/2015 Final version resubmitted on: 28/5/2015

Approved on: 17/6/2015 